\title{
Mining the Built Environment: Telling the Story of Urban Mining
}

\author{
Faisal Aldebei *(D) and Mihály Dombi
}

Citation: Aldebei, F.; Dombi, M. Mining the Built Environment: Telling the Story of Urban Mining. Buildings 2021, 11, 388. https:// doi.org/10.3390/buildings11090388

Academic Editor: Pierfrancesco De Paola

Received: 21 June 2021

Accepted: 14 August 2021

Published: 1 September 2021

Publisher's Note: MDPI stays neutral with regard to jurisdictional claims in published maps and institutional affiliations.

Copyright: (C) 2021 by the authors. Licensee MDPI, Basel, Switzerland. This article is an open access article distributed under the terms and conditions of the Creative Commons Attribution (CC BY) license (https:/ / creativecommons.org/licenses/by/ $4.0 /)$
Department of Environmental Economics, Faculty of Economics and Business, Institute of Economics and World Economy, University of Debrecen, 4032 Debrecen, Hungary; dombi.mihaly@econ.unideb.hu

* Correspondence: faisalaldebei@mailbox.unideb.hu; Tel.: +36-204-387-285

\begin{abstract}
Materials are continuously accumulating in the human-built environment since massive amounts of materials are required for building, developing, and maintaining cities. At the end of their life cycles, these materials are considered valuable sources of secondary materials. The increasing construction and demolition waste released from aging stock each year make up the heaviest, most voluminous waste outflow, presenting challenges and opportunities. These material stocks should be utilized and exploited since the reuse and recycling of construction materials would positively impact the natural environment and resource efficiency, leading to sustainable cities within a grander scheme of a circular economy. The exploitation of material stock is known as urban mining. In order to make these materials accessible for future mining, material quantities need to be estimated and extrapolated to regional levels. This demanding task requires a vast knowledge of the existing building stock, which can only be obtained through labor-intensive, time-consuming methodologies or new technologies, such as building information modeling (BIM), geographic information systems (GISs), artificial intelligence (AI), and machine learning. This review paper gives a general overview of the literature body and tracks the evolution of this research field.
\end{abstract}

Keywords: urban mining; material stock; circular economy; building information modeling (BIM); geographic information systems (GISs)

\section{Introduction}

There has been a surge in interest in the circular economy as a research subject in recent years [1]. According to the present authors, sustainability issues, resource scarcity, waste management, and progressive policies are driving this interest. The traditional economic model takes a linear approach to resource utilization, beginning with extracting raw materials from the natural environment and transforming them into products; these products are discarded as waste in the end-of-life phase. The pollution generated at each step receives little to no attention. In this linear economic model, economic goals take precedence over environmental and social concerns [2]. Economic growth, according to researchers, leads to the depletion of natural resources and a reduction in the natural environment's generative ability [3]. As a result, the circular economy was developed to decouple economic growth from natural resource depletion [4]. However, the term circular economy does not have a fixed definition [1]. It was initially portrayed as a way to achieve a closed-loop material flow within the economic system [5] or a "cradle-to-cradle" system, as McDonough (2007) describes it [6]. One consequence of this interpretation of the circular economy is that it fails to distinguish between distinct types of circularities. As a result, the academic community has primarily focused on closing material loops, where the value of resources is maintained through recycling in what can be described as a "traditional" approach to cleaner production, with much less attention paid toward slowing down the loops [1]. According to Graedel (2011), the recycling efficiency of metals is the sum of the efficiency of each step leading to the production of secondary raw metal [7]. 75 percent of 
waste metals will not be recycled due to losses at each stage. Therefore, it is important to reduce the number of steps by using other forms of circularity.

According to Sauvé et al. (2016), the circular economy model can be a production model that aims to extend the useful life of products by favoring the possibility of repair, refurbishment, and reuse [2]. Slowing materials loops entails creating long-life products, starting with a durable product design; then, its value is extended through remanufacturing, repair, refurbishment, and reuse practices [8]. Many researchers nowadays prefer reuse to recycle or backfilling practices $[9,10]$.

A linear economy based on the take, make, and dispose approach subsequently led to a linear material flow. Coupled with urbanization, an unprecedented amount of material has accumulated in urban systems. The accumulated materials are known as "anthropogenic resources" [11]. In order to describe the size of anthropogenic resources, suffice to imagine that over three hundred years of mining, more than 80 percent of the world's natural resources-resources that could be used for production-were extracted and accumulated above ground. A substantial portion of it is now waste [12]. The anthropogenic stock of gold, silver, lead, and zinc exceeds the known natural deposits, while the anthropogenic stock of copper and iron is equal to known natural deposits [13-17]. Moreover, half of the extracted amounts of copper and iron are no longer in use [18,19]. Furthermore, Krausmann et al. (2017b) estimated that 35 percent of the in-use materials in 2010 will be disposed of as waste by 2030, which is approximately the same amount of waste generated in the last 110 years combined [20]. It is, therefore, safe to assume that the linear model is unsustainable and will lead to the depletion of non-renewable virgin resources. Due to this linear consumption pattern, urbanization, and industrialization, humans have extracted vast amounts of materials, most of which accumulated in urban areas [20-23]. On the one hand, urban areas are considered economic powerhouses, accounting for 85 percent of global GDP [24]. On the other hand, they account for 75 percent of natural resource consumption, 50 percent of global solid waste generation, and 60-80 percent of greenhouse gas emissions [25]. In line with the above, attention was drawn to the exploitation of these anthropogenic resources through a process known as urban mining to replace and complement the extraction of unrenewable natural resources [22,26].

In this paper, we review the development of urban mining as a research subject. Following the introduction section, the research methodology is presented in Section 2. Section 3 introduces the metabolism concept in industrial ecology, the theoretical root for urban mining. In addition, we aimed to organize and classify the literature body to identity urban mining research. In Section 4, an extensive review of urban mining literature from conception until present-day state-of-the-art research and future possibilities is presented. This paper's contributions include (1) analyzing the leading academic research in academic databases and classifying them based on research objectives into four categories: waste management, production and consumption, environmental impacts, and urban mining and secondary resources; (2) comparing related articles concerning their methodologies, research objects, and scopes to track the research evolution and results; and (3) identifying the current research gaps and potential future research directions.

\section{Research Methodology}

Due to the interdisciplinary nature of research on urban mining and material stock and the lack of unified definitions and terminologies, we decided that a systematic review was not the best approach to collect literature; instead, selective snowballing methods were used, as snowballing studies are less affected by diverse terminologies [27]. We started by searching Scopus, Web of Science, and Google Scholar databases for the terms "Urban Mining" and "Material Stock" and after reviewing the results one by one, we chose the most cited paper that matched our scope [14], which was the seed paper for this review. The reason for choosing only one paper was that most of the search results were on e-waste mining. Therefore, these papers did not fall into this review scope. We started a backward snowballing search by looking at the references list from the seed paper and selecting the 
most related paper to our scope. Then, we performed a forward snowballing search from the seed paper and the set of papers extracted from it using the Google scholar "cited by" filter. We continued with the same process, and we stopped the snowballing when no paper relevant to this research could be found. A major drawback of the snowballing methods is that snowballing is affected by the authors' subjective judgments on which papers are worth exploring, and this may result in missing some literature that still falls within the scope of the paper.

\section{Industrial Ecology and Urban Metabolism}

Baccini and Brunner defined the anthroposphere as a "complex system of energy, material, and information fluxes" in their book The Metabolism of the Anthroposphere [26]. They coined the term "anthropogenic metabolism" to describe human society's material and energy turnover, similar to that of living organisms. They noted that the anthroposphere is constantly changing due to man's "biological and cultural needs." Material stock is built up over time as goods that serve as "carriers of materials" accumulate. They also viewed cities as an unhealthy form of accelerated anthroposphere expansion that would eventually collapse due to resource scarcity and pollution.

In this context, the concept of metabolism is not new. Several authors used various approaches to interpret metabolism from a social and industrial standpoint [28]. The term "urban metabolism" was coined by Wolman (1965), who defined it as "the materials and commodities needed to sustain the city's inhabitants, ... The metabolic cycle is not complete until the wastes and residues of daily life have been removed and disposed of with a minimum of nuisance and hazard" [29]. According to Fischer-Kowalski (1998), this definition was the first attempt to conceptualize metabolism in industrial societies [28]. Later, in 2007, Kennedy et al. (2007) defined urban metabolism as "the sum total of the technical and socio-economic processes that occur in cities, resulting in growth, production of energy, and elimination of waste" [30]. The concept has evolved; the term "socioeconomic metabolism" was coined to describe the extended notion of metabolism [31] as the set of all anthropogenic flows, stocks, and transformations of physical resources, as well as their respective dynamics [11,32]. Wolman used mass balance principles to quantify urban metabolism in his 1965 study [33]. This study was a driving force behind creating economy-wide energy and material flow accounts [31]. Studying urban metabolism has gained popularity worldwide, showing the importance of understanding material flows and accumulation processes and how they are critical to cities' sustainability. The result was a perfect storm in academia that propelled material flows and stocks to the forefront of industrial ecology and metabolism research. Today, industrial ecology is a well-established research field that is specifically interested in analyzing material flows and quantifying stocks (both in and out of use) to better understand social, economic, and ecological real-world issues [11,32-35].

\section{The Role of Material Stock in Industrial Ecology Research}

Material stocks are considered the building blocks of society due to their essential social, economic, and ecological roles. Material stock, such as buildings and infrastructures, deliver services to society, such as shelter and transportation. At the same time, they are considered capital containers that require significant monetary investments. Most resource use and emissions that are generated arise from buildings through using and maintaining these stocks [32]. Therefore, the literature on industrial ecology and urban metabolism has a diverse set of goals and drivers. It is also constantly branching out into new fields and applications, with one of these being urban mining. Therefore, categorizing the body of the literature solely based on purpose is difficult. Nonetheless, in Table 1, we attempted to organize the literature into four main categories based on the purpose of each article for the sake of simplicity. However, these categories are interconnected, and many articles fell into more than one category. 
Waste management: This category included all waste and resources efficiency concepts [34,36,37], current recycling and recovery rates, and the future potentials in light of policy frameworks and / or management systems, which are themes that are generally addressed in this category of research. For example, Graedel's (2011) study evaluated the recycling potential of metals in the periodic table and discussed factors influencing recovery rates [7]. Similarly, [35,38] examined copper and zinc global anthropogenic cycles, respectively, to estimate the end-of-life recycling rates. Ciacci et al. (2017) investigated the stock and flow of PVC in the EU-27 countries. Its findings showed that two-thirds of PVC stock are still in use, while one-third is wasted and mostly landfilled with a low recycling rate. Thus, the author proposed several policy interventions [39]. Similar findings were presented in another study [40]. Furthermore, the literature shows an interest in quantifying the current and future waste flows. The general methodology of such research can be described as a retrospective stock pattern estimation that allows a prospective forecasting model for future waste generation to be created [41-53].

Production and consumption: This category included research that focused on the evolution of stocks and flows over time, highlighting the increasing consumption and accumulation of stocks [20,22,49,54-67]. Typically, it included forecasting future demand, similar to the general methodology described in the previous category. Several studies provided indicators based on stock levels, such as materials' saturation in industrialized countries [63-66], and socio-economic indicators, such as the decreasing housing stock in developed countries [67] in contrast to a housing deficit in developing countries [68]. In other words, researchers here attempted to explore and understand the relationship between stock levels and production, consumption, social welfare, population, and income, along with other parameters [60,68-74].

Environmental impacts: A significant part of the literature addressed the ecological implications of material flows and stocks. Many studies examined the correlation between GHG emissions and material stocks [46,75-80], while others estimated wood-based materials or "carbon stock" [81-83], and there was also an interest in analyzing energy use retrospectively [20,84-86] and estimating future energy demand [87-92]. In short, this part of the literature is significant because it presents various scenarios that demonstrate the magnitude of environmental harm that can be averted [52,93], especially in the context of renovation activities and retrofits that extend the life of building stock rather than end it [94-96]. Furthermore, they provide a road map to meet global climate targets $[43,97]$. In addition, there are several growing trends in terms of energy generation technologies and the transition to clean energy. Stock levels, materials requirements, and materials efficiencies are all factors to consider [98-101]. Other studies were more concerned with natural disasters: earthquakes, tsunamis, and floods. They estimated the losses in material stocks that are considered an unexpected waste flow. They also estimate the amounts of material needed to restore previous levels of economic growth [102-105].

Moreover, some studies examined the effect of global warming on the economy, e.g., by estimating lost stock due to the rising sea level $[106,107]$ and the effect of war on stock levels $[108,109]$. However, those might be better suited under the "urban immune system," which is a unifying framework for urban resilience that expands industrial ecology research on urban risk management [110].

Urban mining and secondary resources: This last category includes research that looks at material stock from a future secondary resources standpoint. Any research can be considered an asset for urban mining literature independent of whether the authors refer to urban mining. According to Graedel (2011), three main questions must be answered to assess the potential of urban mining. How many materials are there? When is it going to be available? What form does it take? [7]. Thus, any research that answers one or more of these questions is critical to urban mining as a developing field. 
Table 1. The four categories of material stock research.

\begin{tabular}{|c|c|c|c|c|c|}
\hline Category & Purpose & $\begin{array}{l}\text { Geographical Scope } \\
\text { and Materials }\end{array}$ & $\begin{array}{l}\text { Methodological } \\
\text { Approach }\end{array}$ & $\begin{array}{l}\text { Forecasting } \\
\text { Model }\end{array}$ & Examples \\
\hline $\begin{array}{c}\text { Waste } \\
\text { Management }\end{array}$ & $\begin{array}{l}\text { Forecasting and } \\
\text { comparing future input } \\
\text { and output flows. } \\
\text { Recycling and recovery } \\
\text { rates and policy and } \\
\text { management systems } \\
\text { are reoccurring themes. }\end{array}$ & $\begin{array}{l}\text { Geographical scale: } \\
\text { national and global. } \\
\text { Materials: metals, } \\
\text { construction } \\
\text { aggregates, and } \\
\text { plastic. }\end{array}$ & $\begin{array}{l}\text { Top-down } \\
\text { retrospective } \\
\text { dynamic flow } \\
\text { analysis is } \\
\text { commonly used, } \\
\text { unlike a bottom-up } \\
\text { analysis. }\end{array}$ & Yes & {$[7,38-40]$} \\
\hline $\begin{array}{l}\text { Production and } \\
\text { Consumption }\end{array}$ & $\begin{array}{l}\text { Studies the evolution of } \\
\text { stocks and flows over } \\
\text { time. Forecasting and } \\
\text { comparing future input } \\
\text { and output flows, e.g., } \\
\text { demand for metals. }\end{array}$ & $\begin{array}{l}\text { Geographical scale: } \\
\text { national and global. } \\
\text { Materials: metals, } \\
\text { construction } \\
\text { aggregates. }\end{array}$ & $\begin{array}{l}\text { Top-down } \\
\text { retrospective } \\
\text { dynamic flow } \\
\text { analysis. }\end{array}$ & Yes & $\begin{array}{c}{[20,41,49,} \\
67]\end{array}$ \\
\hline $\begin{array}{l}\text { Environmental } \\
\text { Impacts }\end{array}$ & $\begin{array}{l}\text { Examines the correlation } \\
\text { between GHG } \\
\text { emissions, energy } \\
\text { demand, and material } \\
\text { stocks. Global climate } \\
\text { change and natural } \\
\text { disasters are also } \\
\text { reoccurring topics }\end{array}$ & $\begin{array}{l}\text { Geographical scale: } \\
\text { regional, national, } \\
\text { and global. } \\
\text { Materials: metals, } \\
\text { construction } \\
\text { aggregates, and } \\
\text { wood. }\end{array}$ & $\begin{array}{l}\text { Top-down } \\
\text { retrospective stock } \\
\text { analysis. }\end{array}$ & $\begin{array}{l}\text { Yes, especially } \\
\text { energy demand } \\
\text { and } \\
\text { scenario-based } \\
\text { forecasting. }\end{array}$ & $\begin{array}{l}{[56,77,79,} \\
91]\end{array}$ \\
\hline $\begin{array}{l}\text { Urban Mining } \\
\text { and Secondary } \\
\text { Resources }\end{array}$ & $\begin{array}{l}\text { Estimating material } \\
\text { stock for future } \\
\text { exploitation }\end{array}$ & $\begin{array}{l}\text { Geographical scale: } \\
\text { urban and regional. } \\
\text { Materials: metals, } \\
\text { construction } \\
\text { aggregates, and } \\
\text { wood. }\end{array}$ & $\begin{array}{l}\text { Bottom-up static } \\
\text { stock analysis and } \\
\text { occasionally a } \\
\text { retrospective } \\
\text { dynamic analysis } \\
\text { are performed. }\end{array}$ & $\begin{array}{l}\text { No, instead, some } \\
\text { studies estimate } \\
\text { the demolition } \\
\text { curve. }\end{array}$ & [111-114] \\
\hline
\end{tabular}

\section{Urban Mining}

In 1969, Jane Jacobs put forward the seed of what would later become urban mining. In her book, The Economy of Cities [115], she mentioned that future cities "will become huge, rich and diverse raw materials mines. These mines will differ from any now to be found because they will become richer the longer, they are exploited; new veins, formerly overlooked, will be continually opened." Years after Jacobs, in 1988, Japanese professor Randolph Nanjo noted that the grade of the metals used in products accumulated in the anthroposphere exceeded the grade of natural deposits. He referred to the area of accumulated materials on the Earth's surface as "urban mines" [17]. Mining, which in its traditional sense refers to the extraction of minerals from natural deposits in the Earth's crust, was used to refer to the process of anthropogenic resources utilization and exploitation. Urban mining is, therefore, a metaphor for describing these activities. Similar to traditional mining, which consists of several stages of prospecting, exploration, development, and exploitation, the stages of urban mining begin with prospecting, which entails researching areas with urban mines, then exploration, which entails quantifying the stock, and finally, determining the feasibility of exploitation [22,116-118].

Urban mining is considered one of the strategies for transformation to a circular economy [15,60,119-122]. Urban mining, however, does not have an exact definition but generally refers to the recovery of materials from anthropogenic resources [13]. The term may include energy recovery [123] and product design [7,11]. The concept is known throughout the literature; however, authors used different terms to describe it, such as secondary mining, waste mining, mining above ground, and landfill mining [13]. Although the latter refers to the processing of accumulated waste that is located in waste dumps and structured landfills [124], it originated from the waste management field [14]. According 
to Cossu et al. (1996), landfill mining differs from urban mining; the author argues that the main driver of landfill mining is not the recovery of materials [125]. Urban mining, therefore, extends landfill mining to the process of the recovery of materials $[118,126]$. Perhaps the most comprehensive and inclusive urban mining definition comes from Johansson et al. (2013), which includes in-use stocks, landfills, tailing ponds, slag heaps, hibernating stocks, and dissipated metal resources [13]. However, the literature is still quite divided on what is an appropriate definition for urban mining. For instance, Cossu and Williams (2015) stated that "urban mining should refer to the exploitation of anthropogenic stocks"; the authors further add, "the term is widely used for describing almost any sort of material recycling." The authors argued that material stocks in a defined location, such as buildings and infrastructure, may not vary over time. In contrast, material flows may change from year to year, depending on the economic situation, trends, and technical innovations, making it difficult to estimate the flow since accurately estimating quantities is crucial for urban mining because it is firmly based on economic feasibility [15].

\subsection{Materials under Study}

The urban mining of material stock initially focused on e-waste, motivated by the high concentration of expensive rare earth minerals [15]. In other words, urban mining was considered where economic incentives were high [7]. Then, the focus shifted to hibernating stocks, which are abandoned material stocks that have yet to be collected for waste management [23]. These stocks were soon estimated and realized to be relatively small, accounting for less than $10 \%$ of the anthropogenic stock [127-129]. Again, the focus shifted this time toward in-use stock, driven by industrial ecology and socio-economic metabolism studies [32]. In-use stock, namely, buildings and infrastructure, is the largest anthropogenic stock and the most prominent product of the urban environment. However, in-use stocks are considered the black box of anthropogenic resources [130] due to the difficulty of estimating stock depositories. Several studies have estimated that buildings and infrastructure account for more than 50 percent of all metals used [131], making it the largest urban mine compared to other anthropogenic stocks.

\subsection{Urban Mining Benefits}

The benefits of urban mining go beyond reducing the extraction of non-renewable resources and reducing or eliminating waste to mitigate the environmental impacts of traditional mining [11,14,132]. Graedel (2011) stated, "It should be clear at this point that the successes to date are not very significant or exciting, and that enormous challenges remain. Nevertheless, urban mining does matter. Every kilogram recovered and reused displaces a kilogram that must be mined and processed, with all the environmental, social, and economic implications those actions entail" [7]. In China, for example, aluminum extraction and production accounted for 17,000 kg of greenhouse gases (GHG) per ton in 2008, while recycled aluminum accounted for $715 \mathrm{~kg}$, or 237 times less $[133,134]$. Furthermore, according to another study [135], recycling iron was predicted to save 96.3 million tons of coal and 32.0 million tons of aluminum by 2020, while recycling copper was expected to save 1305.5 million tons of water and eliminate 1255.9 million tons of solid waste. In conclusion, urban mining is essential in the transition toward a circular economy and sustainable cities. Furthermore, it might just be the answer to some deeply-rooted global problems.

\subsection{The Methodological Framework for Urban Mining}

Material flow analysis (MFA) is one of the most widely used methods for examining a specific socio-economic system's material and energy flows. Based on the first law of thermodynamics, "in any process of physical transformation, matter can neither be created nor destroyed". Material inputs are always equal to material outputs plus the material that is stocked, i.e., the build-up, in the system. MFA is defined as "a systematic assessment of the flows and stocks of materials within a system defined in space and time". It connects 
the material's sources, pathways, and intermediate and final sinks [136]. MFA can be applied to any socio-economic system at any scale, such as global and national economies, a specific economic sector, a company, a city, or even a household [20,52,60,74,137,138]. In terms of time, static analysis can capture the material flow and/or stock over a specific period, usually a year, although this is less common [132,139]. Alternatively, dynamic analysis can be used to capture the evolution of material flow and/or stock over a more extended period [20,45]. MFA characteristics make it an attractive tool in resource, waste, and environmental management, as well as secondary resources utilization $[34,136]$. In urban mining, two main methods are typically used: a bottom-up method and a top-down method. Both methods are used for analyzing material flows and stocks with varying degrees of detail [140].

\subsubsection{The Top-Down MFA}

A top-down method is used for larger areas at a macro level, such as global and national economies, over extended periods. Typically, the in-flow data are obtained from macroeconomic statistics, which are typically available. However, outflows are harder to obtain. Therefore, the top-down approach is used in combination with the product's lifetime estimations [141,142]. The results of this method are highly aggregated and lack spatial resolution. Therefore, it has significant limitations and uncertainties when analyzing small geographical areas, such as cities, where there are insufficient statistics $[57,143,144]$. The general theory behind using the top-down method in urban metabolism is that stock accumulation follows per capita wealth. Thus, national figures can be scaled to urban regions, e.g., per capita gross domestic product $[7,137]$.

\subsubsection{The Bottom-Up MFA}

A bottom-up method is a coefficient-based approach for quantifying material stocks and identifying flow behavior $[60,114]$. It entails splitting the stock into distinct material compartments based on their usage (e.g., buildings, vehicles) and then calculating the amounts of material in those compartments by multiplying the material composition indicators, such as the material intensity coefficient, by the physical parameters that define the size of the compartment (e.g., floor area and height). A bottom-up model offers high levels of detail, and the results are typically more accurate than a top-down model. However, this approach is labor- and time-intensive $[138,141]$. To measure the building stocks, the bottom-up method requires field inspections and construction plan analysis, among others. Thus, it is usually used on a narrow scope to evaluate a specific material in a specific year for small geographical areas $[49,141]$. The accuracy of this method is determined by the material under study, the chosen compartment, and the knowledge of material compositions [22]. Therefore, data availability is a significant limitation. A broad scope of research would necessitate a massive amount of data; insufficient or poor-quality data would result in a high amount of uncertainty and inaccurate stock estimations [141]. As a result, a bottom-up approach was used in only 6 studies out of 60 that were reviewed by Müller et al. (2014) [145]. Nonetheless, bottom-up MFA is advantageous in terms of spatial resolution provision. It provides all the necessary details and accurate results for stock estimation or urban mines. In the 2015 study, Professor Tanikawa and his research team emphasized the importance of bottom-up efforts for country-specific studies [138]. This approach, we believe, is the best fit in terms of urban mining and quantifying urban mines because urban mining is a practical tool for change; after all, "Man can think globally but must act locally" [26].

\subsection{The Evolution of Urban Mining Research}

Early research that was focused on forecasting future waste briefly discussed this future waste's availability as secondary resources. Müller (2006) [41] developed a model for forecasting the material demand and waste flow of concrete in Dutch dwellings. Hu et al. (2010) [48] considered iron and steel in Chinese residential buildings in a similar manner. 
Both studies found a decrease in demand and an increase in waste output eventually. Both studies attempted to explain these findings from a variety of perspectives. However, both agreed that the main factor was that the rate of stock accumulation was faster than the rate of waste generation in the early stages of economic development. As the economy expands and more materials accumulate in the system, more waste from aging stocks is generated until the economy reaches a point of material saturation or full economic development. It does not require as many material inputs as it did previously. Because of the long lifespan of durable stocks, such as buildings, demand begins to decline, and the waste generated from old stock increases; however, a recent study showed that the demand for materials in some countries remained high, even after saturation levels, due to maintenance requirements [146]. Muller explained, "stocks are essentially integrals of flows, meaning that relatively small changes in stocks have significant consequences for the flows." This was especially evident in Hu et al.'s findings, which showed that iron and steel waste scrap from residential buildings, if efficiently recycled, could cover or exceed the future demand. A similar approach was used by Hashimoto et al. (2007) [42] to investigate construction minerals and aggregates in Japan for buildings and infrastructures. However, despite the fact that the research revealed a similar trend of decreasing demand, the authors concluded that the amount of waste generated would remain lower than the demand; this indicates a consistent increase in stock or that a significant amount of materials that were previously accounted for as stock are now in their final sink as dead or dissipated stock. It is not always the case that all input materials generate a waste flow in the future. In order to address these constraints in a later study [47], the authors classified construction minerals' input flows into four categories: potential wastes and secondary resources, potential dissipated materials, dissipatively used materials, and permanent structures. This classification system assumes that not all material inputs and stock will generate waste in the future and by excluding non-waste-generating materials, such as missing or dissipated stock, future waste flows and current material stock can be more accurately estimated. However, these studies remain insufficient for accurately quantifying future waste as secondary resources due to many shortcomings. It can be inferred, for example, that this model is highly dependent on the material under study and its pathway. Concrete in infrastructure is more likely to be abandoned and left as hibernating, dead, or dissipated stock. Furthermore, it lacks the spatial resolution of the material compartment, making it impossible to determine the physical location of these missing or dead stocks. This is attributed to the methodological framework since these studies take a top-down approach at a macro-level by considering various parameters that negatively affect the final result, where perhaps the most important examples are the lifespan assumptions [142]. Moreover, a dynamic top-down model requires a long temporal scale for the data to provide an accurate projection. However, this does not consider the variation of material content over time, e.g., renovation activities.

Meanwhile, Lichtensteiger and Baccini (2008) [147] and Wittmer and Lichtensteiger (2007) [44] used a bottom-up approach, what they called the "ark-house method," to study the copper stock in Swiss buildings. This method consists of three steps. It starts with identifying the stock; then, a sample of the stock is physically surveyed and inventoried to determine critical parameters, including the copper content. Finally, a dynamic topdown MFA model was compiled to describe the copper stocks and flows. The goals are to estimate the quantity and quality of copper in building stock and the variations in quantity and quality over time, thus providing more accurate estimates of future availability as secondary resources. Although they chose Switzerland as the system boundary for the data availability at a national level, they argued that Switzerland has the size of a region. Therefore, the method is applicable on a regional or urban scale. Similarly, [46] took the same approach to investigate the Chinese building and infrastructure stock. However, it is still not spatially detailed enough for realistic urban mining estimations. 


\subsection{Overcoming Methodological Limitations}

Despite its shortcomings in quantifying future secondary resources, early studies were essential for opening the black box of stocks and better understanding their behavior. These studies paved the way for more accurate quantifications of stocks. In other words, they provided a proof of concept for urban mining and are considered to be urban mining's early stage of prospection [118]. Nowadays, the bottom-up MFA is described as the second stage of exploration in urban mining. Detailed information about the stock is calculated based on micro-level studies [118]. However, as we pointed out earlier, bottom-up MFA is a time-, labor-, and data-intensive method. Material intensity coefficients (MICs) are needed to calculate the amount of material within the stock when using the bottom-up MFA. MICs are multiplied by the volume of the compartment to calculate the mass of stocked material, which are then aggregated to provide an estimate of the total mass. MICs are similar to density $\left(\mathrm{kg} / \mathrm{m}^{3}\right)$. While the compartment volume represents the actual parameters of the selected compartment, e.g., in building stock, the volume of the building is given in cubic meters. For example, if the steel in a building were to be calculated, the MIC for steel specific to the building and the building volume is needed to calculate how much mass of steel is used in that building. This is a straightforward explanation for a couple of complicated issues. The first is the MICs' availabilities, which will be discussed first in the next section, while the second issue concerning the compartment's physical parameters, e.g., the building's volume and how to acquire such data, will be discussed in the following section.

\subsubsection{Bottom-Up MFA and Material Intensity Coefficients (MICs)}

The MIC datasets are not readily available; they are site-specific and highly affected by local conditions (architectural trend, economic development, etc.) [143]. Therefore, authors typically need to extrapolate MIC data from multiple sources, including a site investigation, architectural data, construction codes and standards, construction blueprints and documents [114,144,148-152], company data [153], energy requirements [130,149], and cadastral maps $[111,112]$. Using a combination of sources is the norm since the data content and quality of information vary considerably between different sources [148], making it an essential practice to reduce uncertainties [154]. MICs research often focuses on residential buildings considering that most of the building stock comprises these buildings [143]. On the other hand, non-residential buildings received less attention [144]. Nevertheless, the general procedure is similar. It can be summarized as follows: buildings are categorized according to several features and characteristics, e.g., building types, such as single-family or multiple-families in case of residential buildings [143,155], or in terms of energy use or energy efficiencies, such as heated non-domestic buildings or social infrastructure in the case of non-residential buildings [144]. Other features include the type of structure $[53,119,154,156]$, or what is generally known as "archetypes" [96,141]. Typically, a few buildings of each category are samples. Then the physical size of the buildings is calculated, e.g., volume $\left(\mathrm{m}^{3}\right)$. Then, the MIC specific to each material is calculated by the means mentioned above as a density $\left(\mathrm{kg} / \mathrm{m}^{3}\right)$. Finally, the result gets generalized to the whole stock, and estimates of material quantities are made. To overcome this complexity, researchers have developed several frameworks that link the materials cycle to the services provided by the products containing the materials while in use rather than the products or the compartments themselves [36]. Instead of investigating a building by volume, it can be done by its service unit, e.g., the floor area $\left(\mathrm{m}^{2}\right)$; in that case, MICs would be in kilograms per service unit. It is worth noting here that, recently, several studies have taken a novel approach driven by circular economy principles. This approach focuses on components that are complex assemblies of materials within buildings, e.g., windows and bricks, rather than focusing on the materials that make up these components to avoid down-cycling. In other words, this approach breaks the building into several components of pre-mixed materials. When estimated and quantified, it gives an idea of the total stock, reducing or eliminating the need for country-, city-, or building-specific MIC 
calculations [10,114,156-159]. As a result, the units of measurement of MICs frequently differ from one study to the next, depending on the material under investigation, the scope of the study, and the availability of data. Therefore, tremendous effort has gone toward collecting and organizing a comprehensive and harmonized MICs database as in $[150,160]$ and [154]; in the latter, for example, the authors collected MIC data from 33 studies and harmonized and reported their findings in a unified unit of kilograms per gross floor area. In a similar context, over the last decade, building information modeling (BIM) has grown in popularity [161]. It can be defined as a digital representation of built objects' physical and functional characteristics [162]. BIM is the backbone of several recent initiatives, such as the EU-funded Buildings as Material Banks project [163]. This project creates "material passports" to provide full and transparent information about buildings, including their material compositions [164]. There are also other commercial projects, e.g., Madaster [165]. However, all the previously mentioned projects involve BIM databases that are primarily populated with newly constructed buildings. In Volk et al.'s (2014) research, the authors reviewed 180 publications on BIM. They concluded that, despite the increasing BIM usage for newly constructed buildings, BIM implementation in existing buildings is still limited. This is due to several factors, such as the effort needed for data collection, modeling, and handling uncertain data and/or objects in buildings [161]. Cheng et al. (2013) presented several BIM systems for existing buildings as a tool for C\&D waste estimation and renovation planning [166]. Recently, Rose and Stegemann (2018) proposed E-BAMB (Existing Buildings as Material Banks), which is an effort to collect and organize free access knowledge about materials stocks in existing buildings [167].

\subsubsection{Material Compartments' Physical Parameters in Bottom-Up Methods}

As discussed earlier, one of the limitations facing the mass adoption of the bottom-up method in studying material stock is acquiring the physical parameters of the stock, primarily pre-existing old stock, which typically lacks proper documentation and requires significant amounts of individual investigation. Modern technologies have significantly aided in the collection and processing of these essential data, where remote sensing was one of the first technologies to be used in this context. For example, the research by Meinel et al. (2009) used topographic maps and geographic information systems (GISs) to analyze building stock [168]; although no MFA was used or a specific material investigated, their study is worth noting because they introduced a new approach to calculate the parameters of urban structures using topographic, digital, and analog maps, combined with statistical data at the municipality level. They mentioned that their method can be used for material flow modeling; they also pointed out the possibility of using maps representing different time slices to analyze the temporal development of the buildings' stock. In the pioneering research of Tanikawa and Hashimoto (2009), a GIS was used to spatially analyze material stock in buildings and infrastructure in combination with a time-series database for temporal analysis. The authors called it a four-dimensional GIS (4D-GIS). The first spatially explicit bottom-up MFA covered $8 \mathrm{~km}^{2}$ in Manchester, UK, and $11 \mathrm{~km}^{2}$ of Wakayama city center, Japan [111]. Although it discussed material availability as secondary resources and the recyclability of materials, this research had a broader scope of investigating the construction materials' distribution in space and time, which enabled the authors to estimate the demolition curve of buildings, hence estimating the average lifespan of the buildings, and finally, to elucidate material accumulation with respect to its vertical location. Several authors have since utilized the same approach in their research. The following summarizes how this technique evolved and was used in different cities, sometimes with significant modifications. Chen et al. (2016) applied a 4D-GIS to estimate the demolition curve in Ezhou City, China [169], while Wang et al. (2019) investigated Longwu village in Shenzhen [170]; Miatto et al. (2019) investigated the city of Padua, Italy [112]; and Guo et al. (2021) investigated Tiexi district, China [171] using the same method. Heeren and Hellweg (2019) used a similar approach but instead of estimating the demolition curve, they provided several scenarios of building renovations in Switzerland [172]. Krook et al. 
(2011) used a GIS to analyze the power infrastructure in Gothenburg and Linköping in Sweden, differentiating between in-use and hibernating stocks of copper in the power networks [23]. Similarly, Wallsten et al. (2015) used a GIS to analyze the hibernating stocks of copper, aluminum, and iron in buildings and infrastructure in the city of Norrköping, Sweden, in which the hibernating metal stocks were mapped using urban districts as the area unit [173]. Marcellus-Zamora et al. (2016) utilized a similar land-use approach [153]. Köhler and Schnitzer (2014) provided an urban mining cadaster using a GIS consisting of industrial and commercial buildings of Darmstadt, Germany [174]. Zhu and Yu (2016) used GIS to form a spatial database of copper, zinc, and steel stocks, which was presented at multiple spatial scales in Australia [137]. Kleemann et al. (2017) calculated the material stock of all buildings in Vienna, Austria, using a GIS [175]. Similarly, Mesta et al. (2019) calculated the material stock of residential buildings in Chiclayo, Peru [151] and Oezdemir et al. (2017) used the same method on residential buildings in Rhine-Ruhr, Germany [130]. Meanwhile, Schebek et al. (2017) calculated material stocks of non-residential buildings in that same area [149]. Cheng et al. (2018) used GIS-based hot spot analysis to detect material stock clustering in Taipei, Taiwan [22]. Similarly, Guo et al. (2019) used the same approach for 14 Chinese metropolitan areas [176]. Gontia et al. (2019) also utilized a similar approach to analyze material stocks with clustering algorithms within GIS software for the city of Gothenburg, Sweden [177].

Other remote sensing methods are used in material stock research. For example, nighttime light (NTL) [141], where early NTL studies found significant correlations between NTL and socio-economic indicators, such as population and GDP [178-181]. These findings are also supported by recent studies based on a new generation of NTL [182-184]. NTL data eliminates the need for the physical parameters of buildings. However, NTL stock studies are often carried out on a large macro-scale using top-down methods, resulting in aggregated estimations that lack spatial detail $[182,185]$. Although several authors attempted to address this issue by narrowing the geographical scope or using NTL in conjunction with MICs at the regional scale, theoretically, the archetypes and typologies are the same [186]. However, as we discuss, these methods are not suitable for urban mining, as it is not spatially detailed enough for accurate stock estimations.

\subsection{Future Research and New Technologies}

With technologies becoming more advanced and affordable, other tools and remote sensing methods that once were exclusive to governments and big corporations are now available to researchers, such as light detection and ranging (LiDAR) technologies [52,187], high-resolution satellite imagery (HRSI) [138,188], and low-altitude drone photography $[189,190]$. All these technologies can capture highly accurate building parameters, footprints, heights, and other dimensions, which subsequently enable accurate stock estimation through bottom-up approaches. Moreover, remote sensing coupled with information and computing technologies, such as big data, artificial intelligence, and machine learning [191] enables the automated, low-cost classification of land use and building typologies. They are making the process of capturing and extracting building parameters in a spatially explicit fashion at all geographical levels an easier task. Nowadays, there are several projects and initiatives in this field, such as SpaceNet.ai, which is an open project that was started in 2016. It offers a repository of freely available precision-labeled buildings and infrastructure on high-resolution satellite imagery as training data for image classification, segmentation, and computer vision. Their datasets include 101 geographical locations, covering $41,000 \mathrm{~m}^{2}$ and a little over eleven million buildings. SpaceNet encourages crowd engagement by organizing challenges anybody can participate in to solve a task or other specific goal, such as building detection, road network detection, and the most recent temporal urban development [192]. The benefits of these new technologies in an urban mining context are that it enables fast, relatively easy, and accurate building parameter detection and thus accurate estimation of the in-use material stocks [193]. We believe that urban mining research will benefit from these technologies in many ways, 
for example, material estimations and localization will only get more accurate. We also predict a widespread adaptation of bottom-up methodologies at a larger geographical scale. Developing countries where traditional urban planning data is lacking will likely join the trend.

Author Contributions: Conceptualization, methodology, investigation, writing-review and editing, F.A.; supervision, M.D. Both authors have read and agreed to the published version of the manuscript.

Funding: This research was supported by the National Research, Development and Innovation Office-NKFIH, K-135907.

Conflicts of Interest: The authors declare no conflict of interest. The funders had no role in the design of the study; in the collection, analyses, or interpretation of data; in the writing of the manuscript; or in the decision to publish the results.

\section{References}

1. Merli, R.; Preziosi, M.; Acampora, A. How do scholars approach the circular economy? A systematic literature review. J. Clean. Prod. 2018, 178, 703-722. [CrossRef]

2. Sauvé, S.; Bernard, S.; Sloan, P. Environmental sciences, sustainable development and circular economy: Alternative concepts for trans-disciplinary research. Environ. Dev. 2016, 17, 48-56. [CrossRef]

3. Lieder, M.; Rashid, A. Towards circular economy implementation: A comprehensive review in context of manufacturing industry. J. Clean. Prod. 2016, 115, 36-51. [CrossRef]

4. Murray, A.; Skene, K.; Haynes, K. The Circular Economy: An Interdisciplinary Exploration of the Concept and Application in a Global Context. J. Bus. Ethics 2017, 140, 369-380. [CrossRef]

5. Geng, Y.; Doberstein, B. Developing the circular economy in China: Challenges and opportunities for achieving "leapfrog development". Int. J. Sustain. Dev. World Ecol. 2008, 15, 231-239. [CrossRef]

6. McDonough, W.; Braungart, M. Remaking the way we make things: Creating a new definition of quality with cradle-to-cradle design. In The International Handbook on Environmental Technology Management; North Point Press: New York, NY, USA, 2002; pp. 33-48.

7. Graedel, T. The prospects for urban mining. Bridge 2011, 41, 43-50.

8. Bocken, N.M.P.; de Pauw, I.; Bakker, C.; van der Grinten, B. Product design and business model strategies for a circular economy. J. Ind. Prod. Eng. 2016, 33, 308-320. [CrossRef]

9. Cooper, D.R.; Gutowski, T.G. The Environmental Impacts of Reuse: A Review. J. Ind. Ecol. 2017, 21, 38-56. [CrossRef]

10. Arora, M.; Raspall, F.; Cheah, L.; Silva, A. Buildings and the circular economy: Estimating urban mining, recovery and reuse potential of building components. Resour. Conserv. Recycl. 2020, 154, 104581. [CrossRef]

11. Baccini, P.; Brunner, P.H. Metabolism of the Anthroposphere. 2012. Available online: https://mitpress.mit.edu/books/ metabolism-anthroposphere-second-edition (accessed on 10 February 2021).

12. Qi, J.; Zhao, J.; Li, W.; Peng, X.; Wu, B.; Wang, H. Urban Mining. In Development of Circular Economy in China; Springer: Singapore, 2016; pp. 247-274. [CrossRef]

13. Johansson, N.; Krook, J.; Eklund, M.; Berglund, B. An integrated review of concepts and initiatives for mining the technosphere: Towards a new taxonomy. J. Clean. Prod. 2013, 55, 35-44. [CrossRef]

14. Krook, J.; Baas, L. Getting serious about mining the technosphere: A review of recent landfill mining and urban mining research. J. Clean. Prod. 2013, 55, 1-9. [CrossRef]

15. Cossu, R.; Williams, I.D. Urban mining: Concepts, terminology, challenges. Waste Manag. 2015, 45, 1-3. [CrossRef] [PubMed]

16. Kapur, A. The future of the red metal-A developing country perspective from India. Resour. Conserv. Recycl. 2006, 47, 160-182. [CrossRef]

17. Nakamura, T.; Halada, K. Potential of urban mine. In SpringerBriefs in Applied Sciences and Technology; Springer: Berlin/Heidelberg, Germany, 2015; pp. 7-29. Available online: https://www.researchgate.net/publication/300363889_Potential_of_Urban_Mine (accessed on 20 October 2020).

18. Müller, D.B.; Wang, T.; Duval, B.; Graedel, T.E. Exploring the engine of anthropogenic iron cycles. Proc. Natl. Acad. Sci. USA 2006, 103, 16111-16116. [CrossRef]

19. UNEP Assessing Global Metal Flows-Metal Stocks in Society and Recycling Rates Economic Development and Metal Use. 2010. Available online: https:/ /wedocs.unep.org/20.500.11822/31433 (accessed on 12 April 2021).

20. Krausmann, F.; Wiedenhofer, D.; Lauk, C.; Haas, W.; Tanikawa, H.; Fishman, T.; Miatto, A.; Schandl, H.; Haberl, H. Global socioeconomic material stocks rise 23 -fold over the 20th century and require half of annual resource use. Proc. Natl. Acad. Sci. USA 2017, 114, 1880-1885. [CrossRef]

21. Schaffartzik, A.; Duro, J.A.; Krausmann, F. Global appropriation of resources causes high international material inequalityGrowth is not the solution. Ecol. Econ. 2019, 163, 9-19. [CrossRef]

22. Cheng, K.L.; Hsu, S.C.; Li, W.M.; Ma, H.W. Quantifying potential anthropogenic resources of buildings through hot spot analysis. Resour. Conserv. Recycl. 2018, 133, 10-20. [CrossRef] 
23. Krook, J.; Carlsson, A.; Eklund, M.; Frändegård, P.; Svensson, N. Urban mining: Hibernating copper stocks in local power grids. J. Clean. Prod. 2011, 19, 1052-1056. [CrossRef]

24. Grubler, A.; Fisk, D. Energizing Sustainable Cities: Assessing Urban Energy. Available online: https://www.semanticscholar.org/ paper/Energizing-sustainable-cities-\%3A-assessing-urban-Grubler-Fisk/e44368c79b9b4d88f72588f3e87010d223f5536e (accessed on 25 March 2021).

25. UNEP Bridging the Emissions Gap: A UNEP Synthesis Report. Available online: https://wedocs.unep.org/handle/20.500.11822 /7996 (accessed on 12 April 2021).

26. Baccini, P.; Brunner, P.H. Metabolism of the Anthroposphere. 1991. Available online: https://books.google.jo/books?id=s2 kYAQAAMAAJ\&q=isbn:9783540537786\&dq=isbn:9783540537786\&hl=en\&sa=X\&redir_esc=y (accessed on 30 January 2021).

27. Jalali, S.; Wohlin, C. Systematic literature studies: Database searches vs. backward snowballing. In Proceedings of the International Symposium on Empirical Software Engineering and Measurement, Lund, Sweden, 21-22 September 2012; pp. 29-38.

28. Fischer-Kowalski, M. Society's Metabolism: The Intellectual History of Materials Flow Analysis, Part I, 1860-1970. J. Ind. Ecol. 1998, 2, 61-78. [CrossRef]

29. Wolman, A. the Metabolism of Cities. Sci. Am. 1965, 213, 179-190. [CrossRef]

30. Kennedy, C.; Cuddihy, J.; Engel-Yan, J. The changing metabolism of cities. J. Ind. Ecol. 2007, 11, 43-59. [CrossRef]

31. Pauliuk, S.; Hertwich, E.G. Socioeconomic metabolism as paradigm for studying the biophysical basis of human societies. Ecol. Econ. 2015, 119, 83-93. [CrossRef]

32. Pauliuk, S.; Müller, D.B. The role of in-use stocks in the social metabolism and in climate change mitigation. Glob. Environ. Chang. 2014, 24, 132-142. [CrossRef]

33. Newell, J.P.; Cousins, J.J. The boundaries of urban metabolism: Towards a political-industrial ecology. Prog. Hum. Geogr. 2015, 39, 702-728. [CrossRef]

34. Guo, D.; Huang, L. The state of the art of material flow analysis research based on construction and demolition waste recycling and disposal. Buildings 2019, 9, 207. [CrossRef]

35. Glöser, S.; Soulier, M.; Tercero Espinoza, L.A. Dynamic analysis of global copper flows. Global stocks, postconsumer material flows, recycling indicators, and uncertainty evaluation. Environ. Sci. Technol. 2013, 47, 6564-6572. [CrossRef] [PubMed]

36. Pfaff, M.; Glöser-Chahoud, S.; Chrubasik, L.; Walz, R. Resource efficiency in the German copper cycle: Analysis of stock and flow dynamics resulting from different efficiency measures. Resour. Conserv. Recycl. 2018, 139, 205-218. [CrossRef]

37. Hao, M.; Wang, P.; Song, L.; Dai, M.; Ren, Y.; Chen, W.Q. Spatial distribution of copper in-use stocks and flows in China: 1978-2016. J. Clean. Prod. 2020, 261. [CrossRef]

38. Meylan, G.; Reck, B.K. The anthropogenic cycle of zinc: Status quo and perspectives. Resour. Conserv. Recycl. 2017, 123, 1-10. [CrossRef]

39. Ciacci, L.; Passarini, F.; Vassura, I. The European PVC cycle: In-use stock and flows. Resour. Conserv. Recycl. 2017, 123, 108-116. [CrossRef]

40. Jiang, X.; Wang, T.; Jiang, M.; Xu, M.; Yu, Y.; Guo, B.; Chen, D.; Hu, S.; Jiang, J.; Zhang, Y.; et al. Assessment of Plastic Stocks and Flows in China: 1978-2017. Resour. Conserv. Recycl. 2020, 161, 104969. [CrossRef]

41. Müller, D.B. Stock dynamics for forecasting material flows-Case study for housing in The Netherlands. Ecol. Econ. 2006, 59, 142-156. [CrossRef]

42. Hashimoto, S.; Tanikawa, H.; Moriguchi, Y. Where will large amounts of materials accumulated within the economy go?-A material flow analysis of construction minerals for Japan. Waste Manag. 2007, 27, 1725-1738. [CrossRef]

43. Noll, D.; Wiedenhofer, D.; Miatto, A.; Singh, S.J. The expansion of the built environment, waste generation and EU recycling targets on Samothraki, Greece: An island's dilemma. Resour. Conserv. Recycl. 2019, 150, 104405. [CrossRef]

44. Wittmer, D.; Lichtensteiger, T. Exploration of urban deposits: Long-term prospects for resource and waste management. Waste Manag. Res. 2007, 25, 220-226. [CrossRef] [PubMed]

45. Augiseau, V.; Barles, S. Studying construction materials flows and stock: A review. Resour. Conserv. Recycl. 2017, 123, 153-164. [CrossRef]

46. Yang, W.; Kohler, N. Simulation of the evolution of the Chinese building and infrastructure stock. Build. Res. Inf. 2008, 36, 1-19. [CrossRef]

47. Hashimoto, S.; Tanikawa, H.; Moriguchi, Y. Framework for estimating potential wastes and secondary resources accumulated within an economy-A case study of construction minerals in Japan. Waste Manag. 2009, 29, 2859-2866. [CrossRef]

48. Hu, M.; Pauliuk, S.; Wang, T.; Huppes, G.; van der Voet, E.; Müller, D.B. Iron and steel in Chinese residential buildings: A dynamic analysis. Resour. Conserv. Recycl. 2010, 54, 591-600. [CrossRef]

49. Fishman, T.; Schandl, H.; Tanikawa, H.; Walker, P.; Krausmann, F. Accounting for the Material Stock of Nations. J. Ind. Ecol. 2014, 18, 407-420. [CrossRef]

50. Wiedenhofer, D.; Steinberger, J.K.; Eisenmenger, N.; Haas, W. Maintenance and Expansion: Modeling Material Stocks and Flows for Residential Buildings and Transportation Networks in the EU25. J. Ind. Ecol. 2015, 19, 538-551. [CrossRef]

51. Deetman, S.; Marinova, S.; van der Voet, E.; van Vuuren, D.P.D.P.; Edelenbosch, O.; Heijungs, R. Modelling global material stocks and flows for residential and service sector buildings towards 2050. J. Clean. Prod. 2020, 245, 118658. [CrossRef]

52. Mastrucci, A.; Marvuglia, A.; Popovici, E.; Leopold, U.; Benetto, E. Geospatial characterization of building material stocks for the life cycle assessment of end-of-life scenarios at the urban scale. Resour. Conserv. Recycl. 2017, 123, 54-66. [CrossRef] 
53. Schandl, H.; Miatto, A. Data on the domestic processed output, balancing items, and solid waste potential for five major world economies. Data Br. 2019, 22, 662-675. [CrossRef]

54. Gassner, A.; Lederer, J.; Fellner, J. Material stock development of the transport sector in the city of Vienna. J. Ind. Ecol. 2020, 24, 1364-1378. [CrossRef]

55. Han, J.; Chen, W.Q.; Zhang, L.; Liu, G. Uncovering the Spatiotemporal Dynamics of Urban Infrastructure Development: A High Spatial Resolution Material Stock and Flow Analysis. Environ. Sci. Technol. 2018, 52, 12122-12132. [CrossRef]

56. Huang, C.; Han, J.; Chen, W.Q. Changing patterns and determinants of infrastructures' material stocks in Chinese cities. Resour. Conserv. Recycl. 2017, 123, 47-53. [CrossRef]

57. Wang, T.; Müller, D.B.; Hashimoto, S. The ferrous find counting iron and steel stocks in China's economy. J. Ind. Ecol. 2015, 19, 877-889. [CrossRef]

58. Song, L.; Wang, P.; Hao, M.; Dai, M.; Xiang, K.; Li, N.; Chen, W.Q. Mapping provincial steel stocks and flows in China: 1978-2050. J. Clean. Prod. 2020, 262, 121393. [CrossRef]

59. Pauliuk, S.; Wang, T.; Müller, D.B. Steel all over the world: Estimating in-use stocks of iron for 200 countries. Resour. Conserv. Recycl. 2013, 71, 22-30. [CrossRef]

60. Schiller, G.; Müller, F.; Ortlepp, R. Mapping the anthropogenic stock in Germany: Metabolic evidence for a circular economy. Resour. Conserv. Recycl. 2017, 123, 93-107. [CrossRef]

61. Song, L.; Zhang, C.; Han, J.; Chen, W.Q. In-use product and steel stocks sustaining the urbanization of Xiamen, China. Ecosyst. Heal. Sustain. 2019, 5, 110-123. [CrossRef]

62. Marinova, S.; Deetman, S.; van der Voet, E.; Daioglou, V. Global construction materials database and stock analysis of residential buildings between 1970-2050. J. Clean. Prod. 2020, 247, 119146. [CrossRef]

63. Müller, D.B.; Wang, T.; Duval, B. Patterns of iron use in societal evolution. Environ. Sci. Technol. 2011, 45, 182-188. [CrossRef] [PubMed]

64. Zhang, T.; Liu, L.; Lv, X. The change in the material stock of urban infrastructures in China. Struct. Chang. Econ. Dyn. 2019, 51, 24-34. [CrossRef]

65. Song, L.; Wang, P.; Xiang, K.; Chen, W.Q. Regional disparities in decoupling economic growth and steel stocks: Forty years of provincial evidence in China. J. Environ. Manag. 2020, 271, 111035. [CrossRef]

66. Bleischwitz, R.; Nechifor, V.; Winning, M.; Huang, B.; Geng, Y. Extrapolation or saturation-Revisiting growth patterns, development stages and decoupling. Glob. Environ. Chang. 2018, 48, 86-96. [CrossRef]

67. Deilmann, C.; Effenberger, K.H.; Banse, J. Housing stock shrinkage: Vacancy and demolition trends in Germany. Build. Res. Inf. 2009, 37, 660-668. [CrossRef]

68. Olaya, Y.; Vásquez, F.; Müller, D.B. Dwelling stock dynamics for addressing housing deficit. Resour. Conserv. Recycl. 2017, 123, 187-199. [CrossRef]

69. Cheng, J.; Shi, F.; Yi, J.; Fu, H. Analysis of the factors that affect the production of municipal solid waste in China. J. Clean. Prod. 2020, 259, 120808. [CrossRef]

70. Fu, C.; Zhang, Y.; Yu, X. How has Beijing's urban weight and composition changed with socioeconomic development? Sci. Total Environ. 2019, 675, 98-109. [CrossRef] [PubMed]

71. Miatto, A.; Schandl, H.; Wiedenhofer, D.; Krausmann, F.; Tanikawa, H. Modeling material flows and stocks of the road network in the United States 1905-2015. Resour. Conserv. Recycl. 2017, 127, 168-178. [CrossRef]

72. Dombi, M.; Karcagi-Kováts, A.; Tóth-Szita, K.; Kuti, I. The structure of socio-economic metabolism and its drivers on household level in Hungary. J. Clean. Prod. 2018, 172, 758-767. [CrossRef]

73. Wang, T.; Zhou, J.; Yue, Y.; Yang, J.; Hashimoto, S. Weight under Steel Wheels: Material Stock and Flow Analysis of High-Speed Rail in China. J. Ind. Ecol. 2016, 20, 1349-1359. [CrossRef]

74. Streeck, J.; Wiedenhofer, D.; Krausmann, F.; Haberl, H. Stock-flow relations in the socio-economic metabolism of the United Kingdom 1800-2017. Resour. Conserv. Recycl. 2020, 161, 104960. [CrossRef]

75. Lanau, M.; Herbert, L.; Liu, G. Extending urban stocks and flows analysis to urban greenhouse gas emission accounting: A case of Odense, Denmark. J. Ind. Ecol. 2021, 25, 961-978. [CrossRef]

76. Müller, D.B.; Liu, G.; Løvik, A.N.; Modaresi, R.; Pauliuk, S.; Steinhoff, F.S.; Brattebø, H. Carbon emissions of infrastructure development. Environ. Sci. Technol. 2013, 47, 11739-11746. [CrossRef] [PubMed]

77. Han, J.; Du, T.; Zhang, C.; Qian, X. Correlation analysis of $\mathrm{CO}_{2}$ emissions, material stocks and economic growth nexus: Evidence from Chinese provinces. J. Clean. Prod. 2018, 180, 395-406. [CrossRef]

78. Han, J.; Meng, X.; Liu, J.; Zhang, Y. The impact of infrastructure stock density on $\mathrm{CO}_{2}$ emissions: Evidence from China provinces. Sustainability 2017, 9, 2312. [CrossRef]

79. Hardadi, G.; Buchholz, A.; Pauliuk, S. Implications of the distribution of German household environmental footprints across income groups for integrating environmental and social policy design. J. Ind. Ecol. 2021, 25, 95-113. [CrossRef]

80. Dombi, M. The service-stock trap: Analysis of the environmental impacts and productivity of the service sector in Hungary. Environ. Res. Lett. 2019, 14, 065011. [CrossRef]

81. Aryapratama, R.; Pauliuk, S. Estimating in-use wood-based materials carbon stocks in Indonesia: Towards a contribution to the national climate mitigation effort. Resour. Conserv. Recycl. 2019, 149, 301-311. [CrossRef] 
82. Kalt, G. Carbon dynamics and GHG implications of increasing wood construction: Long-term scenarios for residential buildings in Austria. Carbon Manag. 2018, 9, 265-275. [CrossRef]

83. Müller, D.B.; Bader, H.P.; Baccini, P. Long-term coordination of timber production and consumption using a dynamic material and energy flow analysis. J. Ind. Ecol. 2004, 8, 65-88. [CrossRef]

84. Carmona, L.G.; Whiting, K.; Wiedenhofer, D.; Krausmann, F.; Sousa, T. Resource use and economic development: An exergy perspective on energy and material flows and stocks from 1900 to 2010. Resour. Conserv. Recycl. 2021, 165. [CrossRef]

85. Haberl, H.; Wiedenhofer, D.; Erb, K.H.; Görg, C.; Krausmann, F. The material stock-flow-service nexus: A new approach for tackling the decoupling conundrum. Sustainability 2017, 9, 1049. [CrossRef]

86. Sandberg, N.H.; Bergsdal, H.; Brattebø, H. Historical energy analysis of the Norwegian dwelling stock. Build. Res. Inf. 2011, 39, 1-15. [CrossRef]

87. Sandberg, N.H.; Sartori, I.; Vestrum, M.I.; Brattebø, H. Using a segmented dynamic dwelling stock model for scenario analysis of future energy demand: The dwelling stock of Norway 2016-2050. Energy Build. 2017, 146, 220-232. [CrossRef]

88. Van Ruijven, B.J.; Van Vuuren, D.P.; Boskaljon, W.; Neelis, M.L.; Saygin, D.; Patel, M.K. Long-term model-based projections of energy use and CO2 emissions from the global steel and cement industries. Resour. Conserv. Recycl. 2016, 112, 15-36. [CrossRef]

89. Albelwi, N.; Kwan, A.; Rezgui, Y. Using Material and Energy Flow Analysis to Estimate Future Energy Demand at the City Level. In Proceedings of the Energy Procedia, Barcelona, Spain, 1-3 February 2017; pp. 440-450.

90. Surahman, U.; Higashi, O.; Kubota, T. Evaluation of current material stock and future demolition waste for urban residential buildings in Jakarta and Bandung, Indonesia: Embodied energy and CO2 emission analysis. J. Mater. Cycles Waste Manag. 2017, 19, 657-675. [CrossRef]

91. Coffey, B.; Borgeson, S.; Selkowitz, S.; Apte, J.; Mathew, P.; Haves, P. Towards a very low-energy building stock: Modelling the US commercial building sector to support policy and innovation planning. Build. Res. Inf. 2009, 37, 610-624. [CrossRef]

92. Hong, L.; Zhou, N.; Feng, W.; Khanna, N.; Fridley, D.; Zhao, Y.; Sandholt, K. Building stock dynamics and its impacts on materials and energy demand in China. Energy Policy 2016, 94, 47-55. [CrossRef]

93. Kakkos, E.; Heisel, F.; Hebel, D.E.D.E.; Hischier, R. Towards urban mining-estimating the potential environmental benefits by applying an alternative construction practice. A case study from Switzerland. Sustainability 2020, 12, 5041. [CrossRef]

94. Wuyts, W.; Miatto, A.; Sedlitzky, R.; Tanikawa, H. Extending or ending the life of residential buildings in Japan: A social circular economy approach to the problem of short-lived constructions. J. Clean. Prod. 2019, 231, 660-670. [CrossRef]

95. Cai, W.; Wan, L.; Jiang, Y.; Wang, C.; Lin, L. Short-Lived Buildings in China: Impacts on Water, Energy, and Carbon Emissions. Environ. Sci. Technol. 2015, 49, 13921-13928. [CrossRef] [PubMed]

96. Vásquez, F.; Løvik, A.N.; Sandberg, N.H.; Müller, D.B. Dynamic type-cohort-time approach for the analysis of energy reductions strategies in the building stock. Energy Build. 2016, 111, 37-55. [CrossRef]

97. Krausmann, F.; Wiedenhofer, D.; Haberl, H. Growing stocks of buildings, infrastructures and machinery as key challenge for compliance with climate targets. Glob. Environ. Chang. 2020, 61, 102034. [CrossRef]

98. Elshkaki, A.; Graedel, T.E. Dynamic analysis of the global metals flows and stocks in electricity generation technologies. J. Clean. Prod. 2013, 59, 260-273. [CrossRef]

99. Li, F.; Ye, Z.; Xiao, X.; Xu, J.; Liu, G. Material stocks and flows of power infrastructure development in China. Resour. Conserv. Recycl. 2020, 160, 104906. [CrossRef]

100. Yang, J.; Zhang, L.; Chang, Y.; Hao, Y.; Liu, G.; Yan, Q.; Zhao, Y. Understanding the material efficiency of the wind power sector in China: A spatial-temporal assessment. Resour. Conserv. Recycl. 2020, 155, 104668. [CrossRef]

101. Cao, Z.; O’Sullivan, C.; Tan, J.; Kalvig, P.; Ciacci, L.; Chen, W.; Kim, J.; Liu, G. Resourcing the Fairytale Country with Wind Power: A Dynamic Material Flow Analysis. Environ. Sci. Technol. 2019, 53, 11313-11322. [CrossRef] [PubMed]

102. Tanikawa, H.; Managi, S.; Lwin, C.M. Estimates of Lost Material Stock of Buildings and Roads Due to the Great East Japan Earthquake and Tsunami. J. Ind. Ecol. 2014, 18, 421-431. [CrossRef]

103. Gallardo, C.; Sandberg, N.H.; Brattebø, H. Dynamic-MFA examination of Chilean housing stock: Long-term changes and earthquake damage. Build. Res. Inf. 2014, 42, 343-358. [CrossRef]

104. Tabata, T.; Morita, H.; Onishi, A. What is the quantity of consumer goods stocked in a Japanese household? Estimating potential disaster waste generation during floods. Resour. Conserv. Recycl. 2018, 133, 86-98. [CrossRef]

105. Tabata, T. Consumer goods in Japanese elderly-only household units: Micro-material stock and earthquake resistance. Int. J. Disaster Risk Reduct. 2020, 51, 101922. [CrossRef]

106. Merschroth, S.; Miatto, A.; Weyand, S.; Tanikawa, H.; Schebek, L. Lost material stock in buildings due to sea level rise from globalwarming: The case of Fiji Islands. Sustainability 2020, 12, 834. [CrossRef]

107. Symmes, R.; Fishman, T.; Telesford, J.N.; Singh, S.J.; Tan, S.Y.; De Kroon, K. The weight of islands: Leveraging Grenada's material stocks to adapt to climate change. J. Ind. Ecol. 2020, 24, 369-382. [CrossRef]

108. Klinglmair, M.; Fellner, J. Historical iron and steel recovery in times of raw material shortage: The case of Austria during World War I. Ecol. Econ. 2011, 72, 179-187. [CrossRef]

109. Aksözen, M.; Hassler, U.; Kohler, N. Reconstitution of the dynamics of an urban building stock. Build. Res. Inf. 2017, 45, 239-258. [CrossRef]

110. Bristow, D.N.; Mohareb, E.A. From the urban metabolism to the urban immune system. J. Ind. Ecol. 2020, 24, 300-312. [CrossRef] 
111. Tanikawa, H.; Hashimoto, S. Urban stock over time: Spatial material stock analysis using 4d-GIS. Build. Res. Inf. 2009, 37, 483-502. [CrossRef]

112. Miatto, A.; Schandl, H.; Forlin, L.; Ronzani, F.; Borin, P.; Giordano, A.; Tanikawa, H. A spatial analysis of material stock accumulation and demolition waste potential of buildings: A case study of Padua. Resour. Conserv. Recycl. 2019, 142, 245-256. [CrossRef]

113. Condeixa, K.; Haddad, A.; Boer, D. Material flow analysis of the residential building stock at the city of Rio de Janeiro. J. Clean. Prod. 2017, 149, 1249-1267. [CrossRef]

114. Arora, M.; Raspall, F.; Cheah, L.; Silva, A. Residential building material stocks and component-level circularity: The case of Singapore. J. Clean. Prod. 2019, 216, 239-248. [CrossRef]

115. Pacione, M. The Economy of Cities; Vintage: New York, NY, USA, 2010; ISBN 0224618261.

116. Lederer, J.; Kleemann, F.; Ossberger, M.; Rechberger, H.; Fellner, J. Prospecting and Exploring Anthropogenic Resource Deposits: The Case Study of Vienna's Subway Network. J. Ind. Ecol. 2016, 20, 1320-1333. [CrossRef]

117. Lederer, J.; Michal, Š.; Franz-Georg, S.; Margarida, Q.; Jiri, H.; Florian, H.; Valerio, F.; Johann, F.; Roberto, B.; Elza, B. What waste management can learn from the traditional mining sector: Towards an integrated assessment and reporting of anthropogenic resources. Waste Manag. 2020, 113, 154-156.

118. Lederer, J.; Laner, D.; Fellner, J. A framework for the evaluation of anthropogenic resources: The case study of phosphorus stocks in Austria. J. Clean. Prod. 2014, 84, 368-381. [CrossRef]

119. Brunner, P.H. Materials Flow Analysis Reshaping Urban Metabolism. Available online: http://www.pik-potsdam.de/ \{\}luedeke/ xws0809/Brunner07.pdf (accessed on 25 October 2020).

120. Cossu, R. The Urban Mining concept. Waste Manag. 2013, 33, 497-498.

121. Pauliuk, S.; Wang, T.; Müller, D.B. Moving toward the circular economy: The role of stocks in the Chinese steel cycle. Environ. Sci. Technol. 2012, 46, 148-154. [CrossRef]

122. Simoni, M.; Kuhn, E.P.; Morf, L.S.; Kuendig, R.; Adam, F. Urban mining as a contribution to the resource strategy of the Canton of Zurich. Waste Manag. 2015, 45, 10-21. [CrossRef]

123. Brunner, P.H.P.H. Urban mining a contribution to reindustrializing the city. Ind. Ecol. 2011, 15, 339-341. [CrossRef]

124. Savage, G.M.; Golueke, C.G.; von Stein, E.L. Landfill mining. Past and present. Biocycle 1993, 34, 58-61.

125. Cossu, R.; Hogland, W.; Salerni, E. Landfill mining in Europe and USA; ISWA: Rotterdam, The Netherlands, 1996; pp. 107-114.

126. Park, J.K.; Clark, T.; Krueger, N.; Mahoney, J. A Review of Urban Mining in the Past, Present and Future. Adv. Recycl. Waste Manag. 2017, 2, 127. [CrossRef]

127. Bergbäck, B.; Lohm, U. Metals in Society. In The Global Environment: Science, Technology and Management; Wiley: Hoboken, NJ, USA, 2008; pp. 276-289. ISBN 9783527619658. [CrossRef]

128. Wallsten, B.; Carlsson, A.; Frändegård, P.; Krook, J.; Svanström, S. To prospect an urban mine-Assessing the metal recovery potential of infrastructure cold spots in Norrköping, Sweden. J. Clean. Prod. 2013, 55, 103-111. [CrossRef]

129. Kapur, A.; Graedel, T.E. Copper mines above and below the ground. Environ. Sci. Technol. 2006, 40, 3135-3141. [CrossRef]

130. Oezdemir, O.; Krause, K.; Hafner, A. Creating a resource cadaster-A case study of a district in the Rhine-Ruhr metropolitan area. Buildings 2017, 7, 45. [CrossRef]

131. Van Beers, D.; Graedel, T.E. Spatial characterisation of multi-level in-use copper and zinc stocks in Australia. J. Clean. Prod. 2007, 15, 849-861. Available online: https://www.sciencedirect.com/science/article/abs/pii/S0959652606002319?via\%3Dihub (accessed on 5 January 2021). [CrossRef]

132. Gerst, M.D. Linking material flow analysis and resource policy via future scenarios of in-use stock: An example for copper. Environ. Sci. Technol. 2009, 43, 6320-6325. [CrossRef]

133. Ding, N.; Gao, F.; Wang, Z.H.; Gong, X.Z. Comparative analysis of primary aluminum and recycled aluminum on energy consumption and greenhouse gas emission. Zhongguo Youse Jinshu Xuebao/Chin. J. Nonferrous Met. 2012, 22, $2908-2915$.

134. Li, S.; Zhang, T.; Niu, L.; Yue, Q. Analysis of the development scenarios and greenhouse gas (GHG) emissions in China's aluminum industry till 2030. J. Clean. Prod. 2021, 290, 125859. [CrossRef]

135. Wen, Z.; Zhang, C.; Ji, X.; Xue, Y. Urban Mining's Potential to Relieve China's Coming Resource Crisis. J. Ind. Ecol. 2015, 19, 1091-1102. [CrossRef]

136. Brunner, P.H.; Rechberger, H. Practical Handbook of Material Flow Analysis; CRC Press: Boca Raton, FL, USA, 2016. [CrossRef]

137. Zhu, X.; Yu, X. Above-Ground Resource Analysis with Spatial Resolution to Support Better Decision Making. J. Sustain. Metall. 2016, 2, 304-312. [CrossRef]

138. Tanikawa, H.; Fishman, T.; Okuoka, K.; Sugimoto, K. The weight of society over time and space: A comprehensive account of the construction material stock of Japan, 1945-2010. J. Ind. Ecol. 2015, 19, 778-791. [CrossRef]

139. Haas, W.; Krausmann, F.; Wiedenhofer, D.; Heinz, M. How circular is the global economy?: An assessment of material flows, waste production, and recycling in the European union and the world in 2005. J. Ind. Ecol. 2015, 19, 765-777. [CrossRef]

140. Guidelines for Data Modeling and Data Integration for Material Flow Analysis and Socio-Metabolic Research; Board of the Topical Section for Research on Socio-Economic Metabolism (SEM) of the International Society for Industrial Ecology (ISIE): Freiburg, Germany, 2021. [CrossRef]

141. Lanau, M.; Liu, G.; Kral, U.; Wiedenhofer, D.; Keijzer, E.; Yu, C.; Ehlert, C. Taking Stock of Built Environment Stock Studies: Progress and Prospects. Environ. Sci. Technol. 2019, 53, 8499-8515. [CrossRef] [PubMed] 
142. Miatto, A.; Schandl, H.; Tanikawa, H. How important are realistic building lifespan assumptions for material stock and demolition waste accounts? Resour. Conserv. Recycl. 2017, 122, 143-154. Available online: https:/ /www.sciencedirect.com/science/article/ abs/pii/S0921344917300265?via\%3Dihub (accessed on 23 February 2021). [CrossRef]

143. Gontia, P.; Nägeli, C.; Rosado, L.; Kalmykova, Y.; Österbring, M. Material-intensity database of residential buildings: A case-study of Sweden in the international context. Resour. Conserv. Recycl. 2018, 130, 228-239. [CrossRef]

144. Ortlepp, R.; Gruhler, K.; Schiller, G. Material stocks in Germany's non-domestic buildings: A new quantification method. Build. Res. Inf. 2016, 44, 840-862. [CrossRef]

145. Müller, E.; Hilty, L.M.; Widmer, R.; Schluep, M.; Faulstich, M. Modeling metal stocks and flows: A review of dynamic material flow analysis methods. Environ. Sci. Technol. 2014, 48, 2102-2113. [CrossRef] [PubMed]

146. Fishman, T.; Schandl, H.; Tanikawa, H. Stochastic Analysis and Forecasts of the Patterns of Speed, Acceleration, and Levels of Material Stock Accumulation in Society. Environ. Sci. Technol. 2016, 50, 3729-3737. [CrossRef]

147. Lichtensteiger, T.; Baccini, P. Exploration of Urban Stocks. J. Environ. Eng. Manag. 2008, 18, 41-48. Available online: https: //www.dora.lib4ri.ch/eawag/islandora/object/eawag\%3A5782 (accessed on 5 February 2021).

148. Kleemann, F.; Lederer, J.; Aschenbrenner, P.; Rechberger, H.; Fellner, J. A method for determining buildings material composition prior to demolition. Build. Res. Inf. 2016, 44, 51-62. [CrossRef]

149. Schebek, L.; Schnitzer, B.; Blesinger, D.; Köhn, A.; Miekley, B.; Linke, H.J.H.J.; Lohmann, A.; Motzko, C.; Seemann, A. Material stocks of the non-residential building sector: The case of the Rhine-Main area. Resour. Conserv. Recycl. 2017, 123, 24-36. [CrossRef]

150. Yang, D.; Guo, J.; Sun, L.; Shi, F.; Liu, J.; Tanikawa, H. Urban buildings material intensity in China from 1949 to 2015. Resour. Conserv. Recycl. 2020, 159, 104824. [CrossRef]

151. Mesta, C.; Kahhat, R.; Santa-Cruz, S. Geospatial Characterization of Material Stock in the Residential Sector of a Latin-American City. J. Ind. Ecol. 2019, 23, 280-291. [CrossRef]

152. Lanau, M.; Liu, G. Developing an Urban Resource Cadaster for Circular Economy: A Case of Odense, Denmark. Environ. Sci. Technol. 2020, 54, 4675-4685. [CrossRef]

153. Marcellus-Zamora, K.A.; Gallagher, P.M.; Spatari, S.; Tanikawa, H. Estimating Materials Stocked by Land-Use Type in Historic Urban Buildings Using Spatio-Temporal Analytical Tools. J. Ind. Ecol. 2016, 20, 1025-1037. [CrossRef]

154. Heeren, N.; Fishman, T. A database seed for a community-driven material intensity research platform. Sci. Data 2019, 6, 23. [CrossRef] [PubMed]

155. Romero Perez de Tudela, A.; Rose, C.M.; Stegemann, J.A. Quantification of material stocks in existing buildings using secondary data-A case study for timber in a London Borough. Resour. Conserv. Recycl. X 2020, 5, 100027. [CrossRef]

156. Ergun, D.; Gorgolewski, M. Inventorying Toronto's single detached housing stocks to examine the availability of clay brick for urban mining. Waste Manag. 2015, 45, 180-185. [CrossRef]

157. Ajayebi, A.; Hopkinson, P.; Zhou, K.; Lam, D.; Chen, H.M.; Wang, Y. Spatiotemporal model to quantify stocks of building structural products for a prospective circular economy. Resour. Conserv. Recycl. 2020, 162, 105026. [CrossRef]

158. Akanbi, L.A.; Oyedele, A.O.; Oyedele, L.O.; Salami, R.O. Deep learning model for Demolition Waste Prediction in a circular economy. J. Clean. Prod. 2020, 274, 122843. [CrossRef]

159. Heisel, F.; Rau-Oberhuber, S. Calculation and evaluation of circularity indicators for the built environment using the case studies of UMAR and Madaster. J. Clean. Prod. 2020, 243, 118482. [CrossRef]

160. Schiller, G.; Miatto, A.; Gruhler, K.; Ortlepp, R.; Deilmann, C.; Tanikawa, H. Transferability of Material Composition Indicators for Residential Buildings: A Conceptual Approach Based on a German-Japanese Comparison. J. Ind. Ecol. 2019, $23,796-807$. [CrossRef]

161. Volk, R.; Stengel, J.; Schultmann, F. Building Information Modeling (BIM) for existing buildings—Literature review and future needs. Autom. Constr. 2014, 38, 109-127. [CrossRef]

162. ISO Organization and Digitization of Information about Buildings and Civil Engineering Works, Including Building Information Modelling (BIM)_Information Management Using Building Information Modelling_Part 1: Concepts and Principles; ISO 19650-1:2018; International Organization for Standardization: Geneva, Switzerland, 2018.

163. BAMB Buildings As Material Banks (BAMB2020)—BAMB 2015. Available online: https://www.bamb2020.eu/ (accessed on 18 December 2020).

164. Luscuere, L.M. Materials Passports: Optimising value recovery from materials. Waste Resour. Manag. 2017, 170, 25-28. [CrossRef]

165. Madaster Madaster-The Digital Library of Materials. Available online: https://madaster.com/ (accessed on 1 June 2021).

166. Cheng, J.C.P.; Ma, L.Y.H. A BIM-based system for demolition and renovation waste estimation and planning. Waste Manag. 2013, 33, 1539-1551. [CrossRef]

167. Rose, C.M.; Stegemann, J.A. Characterising existing buildings as material banks (E-BAMB) to enable component reuse. Proc. Inst. Civ. Eng. Eng. Sustain. 2018, 172, 129-140. [CrossRef]

168. Meinel, G.; Hecht, R.; Herold, H. Analyzing building stock using topographic maps and GIS. Build. Res. Inf. 2009, 37, 468-482. [CrossRef]

169. Chen, C.; Shi, F.; Okuoka, K.; Tanikawa, H. The Metabolism Analysis of Urban Building by 4d-GIS-A Useful Method for New-type Urbanization Planning in China. Univers. J. Mater. Sci. 2016, 4, 40-46. [CrossRef]

170. Wang, H.; Chen, D.; Duan, H.; Yin, F.; Niu, Y. Characterizing urban building metabolism with a 4D-GIS model: A case study in China. J. Clean. Prod. 2019, 228, 1446-1454. [CrossRef] 
171. Guo, J.; Fishman, T.; Wang, Y.; Miatto, A.; Wuyts, W.; Zheng, L.; Wang, H.; Tanikawa, H. Urban development and sustainability challenges chronicled by a century of construction material flows and stocks in Tiexi, China. J. Ind. Ecol. 2021, 25, 162-175. [CrossRef]

172. Heeren, N.; Hellweg, S. Tracking Construction Material over Space and Time: Prospective and Geo-referenced Modeling of Building Stocks and Construction Material Flows. J. Ind. Ecol. 2019, 23, 253-267. [CrossRef]

173. Wallsten, B.; Magnusson, D.; Andersson, S.; Krook, J. The economic conditions for urban infrastructure mining: Using GIS to prospect hibernating copper stocks. Resour. Conserv. Recycl. 2015, 103, 85-97. [CrossRef]

174. Köhler, T.; Schnitzer, B. Urban Mining Cadastre-A Geospatial Data Challenge; In Proceedings of XXV International International Federation of Surveyors (FIG) Congress; Kuala Lumpur, Malaysia, 16-21 June 2014.

175. Kleemann, F.; Lederer, J.; Rechberger, H.; Fellner, J. GIS-based Analysis of Vienna's Material Stock in Buildings. J. Ind. Ecol. 2017, 21, 368-380. [CrossRef]

176. Guo, J.; Miatto, A.; Shi, F.; Tanikawa, H. Spatially explicit material stock analysis of buildings in Eastern China metropoles. Resour. Conserv. Recycl. 2019, 146, 45-54. [CrossRef]

177. Gontia, P.; Thuvander, L.; Wallbaum, H. Spatiotemporal characteristics of residential material stocks and flows in urban, commuter, and rural settlements. J. Clean. Prod. 2020, 251, 119435. [CrossRef]

178. Rauch, J.N. Global mapping of $\mathrm{Al}, \mathrm{Cu}, \mathrm{Fe}$, and Zn in-use stocks and in-ground resources. Proc. Natl. Acad. Sci. USA 2009, 106, 18920-18925. [CrossRef] [PubMed]

179. Takahashi, K.I.; Terakado, R.; Nakamura, J.; Adachi, Y.; Elvidge, C.D.; Matsuno, Y. In-use stock analysis using satellite nighttime light observation data. Resour. Conserv. Recycl. 2010, 55, 196-200. [CrossRef]

180. Elvidge, C.D.; Baugh, K.E.; Kihn, E.A.; Kroehl, H.W.; Davis, E.R.; Davis, C.W. Relation between satellite observed visible-near infrared emissions, population, economic activity and electric power consumption. Int. J. Remote Sens. 1997, 18, 1373-1379. [CrossRef]

181. Chen, X.; Nordhaus, W.D. Using luminosity data as a proxy for economic statistics. Proc. Natl. Acad. Sci. USA 2011, 108, 8589-8594. [CrossRef]

182. Liang, H.; Dong, L.; Tanikawa, H.; Zhang, N.; Gao, Z.; Luo, X. Feasibility of a new-generation nighttime light data for estimating in-use steel stock of buildings and civil engineering infrastructures. Resour. Conserv. Recycl. 2017, 123, 11-23. [CrossRef]

183. Yu, B.; Deng, S.; Liu, G.; Yang, C.; Chen, Z.; Hill, C.J.; Wu, J. Nighttime Light Images Reveal Spatial-Temporal Dynamics of Global Anthropogenic Resources Accumulation above Ground. Environ. Sci. Technol. 2018, 52, 11520-11527. [CrossRef]

184. Zhu, X.; Lane, R.; Werner, T.T. Modelling in-use stocks and spatial distributions of household electronic devices and their contained metals based on household survey data. Resour. Conserv. Recycl. 2017, 120, 27-37. [CrossRef]

185. Vilaysouk, X.; Islam, K.; Miatto, A.; Schandl, H.; Murakami, S.; Hashimoto, S. Estimating the total in-use stock of Laos using dynamic material flow analysis and nighttime light. Resour. Conserv. Recycl. 2021, 170, 105608. [CrossRef]

186. Peled, Y.; Fishman, T. Title: Estimation and mapping of the material stocks of buildings of Europe: A novel nighttime lights-based approach. Resour. Conserv. Recycl. 2021, 169, 105509. [CrossRef]

187. Schandl, H.; Marcos-Martinez, R.; Baynes, T.; Yu, Z.; Miatto, A.; Tanikawa, H. A spatiotemporal urban metabolism model for the Canberra suburb of Braddon in Australia. J. Clean. Prod. 2020, 265, 121770. [CrossRef]

188. Hecht, R.; Kunze, C.; Hahmann, S. Measuring completeness of building footprints in openstreetmap over space and time. ISPRS Int. J. Geo-Inf. 2013, 2, 1066-1091. [CrossRef]

189. Lu, R.S. Research on the mapping of large-scale topographic maps based on low-altitude drone aerial photography system. In Proceedings of the International Archives of the Photogrammetry, Remote Sensing and Spatial Information Sciences, Volume XLII-3/W10, 2020 International Conference on Geomatics in the Big Data Era (ICGBD), Guilin, China, 15-17 November 2019; pp. 623-628. [CrossRef]

190. Risbøl, O.; Gustavsen, L. LiDAR from drones employed for mapping archaeology-Potential, benefits and challenges. Archaeol. Prospect. 2018, 25, 329-338. [CrossRef]

191. Buffat, R.; Froemelt, A.; Heeren, N.; Raubal, M.; Hellweg, S. Big data GIS analysis for novel approaches in building stock modelling. Appl. Energy 2017, 208, 277-290. [CrossRef]

192. SpaceNet spacenet.ai-Accelerating Geospatial Machine Learning. Available online: https://spacenet.ai/ (accessed on 2 June 2021).

193. Hudson, P. Urban Characterisation; Expanding Applications for, and New Approaches to Building Attribute Data Capture. Hist. Environ. Policy Pract. 2018, 9, 306-327. [CrossRef] 